\title{
The Profound Sense of Dissatisfaction: A Comparative Study of Franz Kafka's $A$ Hunger Artist and Maulana Jalalu-d'-Din Muhammad i Rumi's $A$ Man of Baghdad
}

\author{
Noorbakhsh Hooti \\ Razi University, Faculty of Arts, English Department, Kermanshah, Iran \\ E-mail: nhooti@yahoo.com \\ Mohammad Reza Moradi Borna \\ Razi University, Kermanshah, Iran
}

Doi:10.7575/aiac.alls.v.5n.1p.53

URL: http://dx.doi.org/10.7575/aiac.alls.v.5n.1p.53
Received: 02/01/2014

Accepted: 26/02/2014

\begin{abstract}
This study delves into investigating Kafka's A Hunger Artist and Rumi's A Man of Baghdad, in which they have dramatized sense of dissatisfaction, its causes and consequences in a symbolic manner. In fact, it has utilized the story of Rumi that its main character is in a condition similar to the main character in Kafka's story. In both stories the main characters somehow are imprisoned in their ideals, and what distinguishes between these two stories is the different viewpoints that they adopt in confronting their ideals. Actually, the limited view of human beings and being detached from reality, and actually being detached from themselves, has been considered the main cause of dissatisfaction. So, the flagrant relationship among human ideals, enjoyment, and suffering is resulted from their intangible borders. Therefore, the purpose of this article is to reveal the human choices in searching for happiness, escaping from the sense of dissatisfaction, and manifold encounters with reality, and ultimately attaching to the ideals that are embedded in the themes of the both stories.
\end{abstract}

Keywords: Kafka, Rumi, Dissatisfaction, Limited View

\section{Introduction}

Dissatisfaction can be viewed as a feeling, which may indicate you lack the satisfying mental solace, and what you have gained is not that you deserve, or the circumstances in which you are placed, are not as perfect it ought to be to make you satisfied. In fact, some events must occur in the future, and some changes must take place in the world so that you can reach the sense of perfection. Krishnamurti states: "Your consciousness, with which you have identified yourself as your 'individual' consciousness, is an illusion. It is the consciousness of the rest of mankind".(1984, p.68). As a matter of fact, it can be stated that displeasure is the product of conflicts, conflicts which start growing in human minds and generally as human life goes on, its conflicts become more tangible, and these conflicts can cause more dissatisfaction; the conflicts that are resulted from the different ways that are situated in front of the individual and he must choose. Since he does not have an accurate criterion for his choices, he somehow rambles between the different ways. So, he finds the best way to escape from the dilemma, resorting to ideals. So, he deprives himself of thinking about other ways; in fact, he deprives himself of thinking about life.

\section{An outline of $\boldsymbol{A}$ Hunger Artist}

A Hunger Artist is about an artist, who by showing his ability in bearing hunger for a long time in a cage, tries to attract people's attention. He is honest in what he does, and he extremely wants people to trust him, and people's suspicion towards his ability irritates him and makes him dissatisfied. After some time, people lose their interest in watching his shows and nobody comes to watch him. So, he goes to a circus and there, in a cage close to other animals performs his show hoping to be seen, but again there, people rarely come to watch him and mostly prefer to watch the passionate animals. Finally the supervisor of the circus orders to take him off the cage and put a young panther in his place, when people see the panther, they get excited and a mass of crowd come to watch the young panther.

\section{An outline of $\boldsymbol{A}$ Man of Baghdad}

The present story dramatizes a man from Baghdad, who is in great distress and in his dream, he sees the place of a treasure in Egypt. So, he travels to Egypt to find the treasure. When he arrives there, a guard who thinks he is a thief arrests him and starts beating him. The man from Baghdad explains his reasons for coming there, and the guard believes what he says. The guard tells him that he has seen a treasure in his dreams several times likewise, but the guard calls the man a foolish person, because of coming there to find the treasure. The treasure that the guard used to see in his dreams 
is in Baghdad and indeed, in the house of the man from Baghdad. So, the man from Baghdad returns to Baghdad and finds the treasure.

\section{Internal Sense of Dissatisfaction}

In human mind, there is a gap between what is and what ought to be. When it is not pleasant, some ideals start shaping in human mind, and man loathes reality. It causes the man to look at far beyond and try to find happiness somewhere else. Making and having ideals are the easiest job to escape from reality. Heidegger believes:

The last man must move in a realm of ideas which blink at everything and can do nothing else but blink, in consequence of an unearthly fate that forbids modern man to look beyond himself and his type of ideas.(1968, p.83).

So, the more ideals expand, the more human being goes farther from the reality and himself, as far as he cannot recognize the difference between reality and fantasy. In fact, he reaches a point that he only can live by ideals and dissatisfaction with the status quo. In the modern world which is full of motley and glamorous ideals, most people live in a cage of ideals, a cage that from their point of view is so beautiful, and there is no desire to leave the autistic cell.

From an analytic point, the inner richness makes human accept the realities of life, but the bedridden cultures that assign more possessing and soliciting, basic terms for being blissful and successful, put human being in a dilemma where he must choose between wanting and struggling for more or having a natural life along with serenity and satisfaction, but generally human gets in line with the medium culture. So, he struggles much more than what is necessary for a happy and healthy life and exclude himself from the beauties of life. Tolle opines: "Most people in their restless search for something significant to happen to them, continuously miss the insignificant, which may not be insignificant at all.”(2005, p.142). So the predominant sense which he mostly feels is nothing except discontent and insecurity. So with these qualities the human commits to his demands, a tremendous commitment, which will overshadow his life. He inevitably builds a wall around himself to keep himself from the minatory factors that can challenge his future and ideals. So, many aspects of life become pointless to him and he transforms into a one-dimensional person, who has lost the sense of creativity in his actions. His relationship with others will be based on personal interests and desires, and also loses the ability of enjoying life and its simplicities. Eventually, he may become a person who lives in seclusion, where his soul is not satisfied with this state, but he is extremely faithful to his demands and is stranded on an island which is surrounded by discontent. Throughout human history, a great number of utopias have been offered to human being by the various schools of thought. In other words, human beings have been offered a place free from suffering where everything is desirable, and each one of them has shown a different way to achieve perfection. Every human being, based on his experiences and mental backgrounds, has a specific definition of happiness in his mind, and this can be besides the ideals that differ in different intellectual schools. Every man has some ideals in his mind and tries to achieve his personal ideals. This study describes each individual's personal ideals that determine his path of life, character, and even his social status. In other words, every human being can be defined by his ideals; the ideals that can be true or false or can be hidden in his subconscious mind, in a way that he may not be aware of. Human ideals portend prosperity and happiness, and make him try to get himself closer to them. On the other hand, the ideals limit human minds and set a specific thing as the only way to achieve happiness. So, as much as human ideals are great and respectful, he is still a limited and one-dimensional person that is incapable of understanding the totality of life. In truth, our argument is not concerned with the evil or normative ideals, but the matter is the sense of contention that cannot be grasped merely by regarding one dimension of life. So, all aspects of life are interconnected and have influence on each other. If a person only looks at a separate part of life, but ignores the rest, cannot have a genuine cognition of himself and as well as the life, even if he has a wide range of ideals in his mind. Indeed, because of his lack of understanding of the other factors, which impact on his life, everything he achieves can be affected and changed by the other effective factors, although may not be what he has desired. So, he would not reach satisfaction. Therefore, life has pleasant and unpleasant aspects that both must be considered in selecting targets. If human being just desires to be satisfied and looks at the world with a limited view, there will be lots of factors that can dissatisfy him.

\section{The Failure of Idealistic Satisfaction}

Kafka's story introduces the main character as a hunger artist who by bearing hunger for a long time tries to draw the audience's admiration. Here again, there can be a symbolic contradiction that is dramatized by showing needlessness to physical food, at the same time the need for attracting people to see him or somehow gain a mental nourishment. In fact hunger and suffering that he imposes on himself can be the symbols of agonies that human being catches in society. In this story in a hyperbolic manner, it has been tried to portray the agonies that human soul suffers from; that is the excruciated soul that has brought objectivity to itself in a physically thin and weak body inside a cage, and a man who has chosen being in a cage and actually cares about other people's judgment. He enjoys being seen and observed by the others as if he would feel safe by doing this; he is a character, who is afraid of being free, but struggles to seem extraordinary. So, he makes an attempt to attract the positive judgments of the others by torturing himself in the cage to fill the gap that is in his existence. Other's suspicion to his ability extremely excruciates him; the following extract shows this matter:

for the initiates knew well enough that during his fast the artist would never in any circumstances, not even under forcible compulsion, swallow the smallest morsel of food; the honor of his profession forbade it. Not every watcher, of course, was capable of understanding this, there were often groups of night watchers who 
were very lax in carrying out their duties and deliberately huddled together in a retired corner to play cards with great absorption, obviously intending to give the hunger artist the chance of a little refreshment, which they supposed he could draw from some private hoard. Nothing annoyed the artist more than such watchers; they made him miserable; they made his fast seem unendurable; sometimes he mastered his feebleness sufficiently to sing during their watch for as long as he could keep going, to show them how unjust their suspicions were. But that was of little use; they only wondered at his cleverness in being able to fill his mouth even while singing.(Kafka, 1971, pp.301-302).

As the title of the story presents this story shows, an artist and somehow implicitly refers to hunger. In fact, the artist's attempt to attract the audience can pretend his mental hunger that he suffers from, the immense need for being seen. Here, an artist has been dramatized, who in a passive way is trying to prove his abilities, and actually by imposing hunger on himself seeks something, which is so important to him. On the other side, in Rumi's story the Baghdadi man, in a different manner and actively travels to a far place. The hunger artist and the Baghdadi man seek something, and actually, they go to fulfill their desires alike. The common point in two stories can be that both characters in these stories by following an ideal try to fulfill their desideration. In A Hunger Artist, Kafka somehow has sympathized with the hunger artist and his torment, but he does not consider anybody blameworthy, and what he has dramatized, encounters different thoughts and desires. The short story also challenges the social ethics and scrutinizes a person, who tries to be a moral and an honest person as the people wish, but nobody believes him; ethics that seem to be baseless and nobody cares about them, except the hunger artist. It seems that he has been suffering from the other people's negligence towards his honesty in his work, and in a symbolic manner, this can dramatize the negligence of the people to ethics in the modern time in which nobody expects honesty and truthfulness from the others, and this negligence extremely irritates him. The following extract of the short story can show the same:

For he alone knew, what no other initiate knew, how easy it was to fast. It was the easiest thing in the world. He made no secret of this, yet people did not believe him, at the best they set him down as modest, most of them, however, thought he was out for publicity or else was some kind of cheat who found it easy to fast because he had discovered a way of making it easy, and then had the impudence to admit the fact, more or less.(Kafka, 1971, pp.302-303).

The hunger artist, in the cage has separated himself from the other people, and without communicating with people, attempts to prove himself to the other people. So, this matter can be because of his fear from facing the reality whatever he cares about; actually, an ideal that maybe for the other people is just such a trivial thing that people consider it mere entertainment. Hence, he cannot have a genuine understanding of people's opinions, and mutually the people cannot properly understand his intentions. In Rumi's story, when the Baghdadi man faces the guard, while the guard assumes that he is a thief, starts beating him. He talks to the guard and explains the reason of his coming to that city. So, at the end, the guard believes in what he says. Therefore, here the Baghdadi man entails himself in communicating with the others, and actually, involves himself in the flow of life. Through his all power, he tries to reveal the reality of his intentions. Both the Baghdadi man and the hunger artist are honest in what they do, but the only difference between them is their approach in encountering other people, so this difference can have led to absolutely different results. To be honest, the limited view of human being towards life is one of the most important causes of dissatisfaction and suffering. Life gives the human being lots of opportunities, but when he just looks at one single part of its innumerable aspects and when he cannot be successful in that part he will be full of sense of dissatisfaction. Here, Kafka concisely shows the hunger artist's limited view: "for adopting another profession, he was not only too old for that but too fanatically devoted to fasting." (Kafka, 1971, 306). Actually, when the hunger artist loses his spectators, he does not desist following his ideal and by feeling a deep sense of dissatisfaction again sought satisfaction. In Rumi's story, the Baghdadi man, who is in great distress, follows a new ideal, and in order to gain that travels to a far place. Actually, he was not attached to a special aspect of life and tried to examine the different ways; however, it cannot be said that the Baghdadi man chose the right way. Here, what is important is that he was not sure of the correctness of his ideal, and simply by venturing tried to examine its correctness.

Therefore, the man who is honest in his job and thinks he is a righteous person, at the same time is strongly dissatisfied. Here, he considers himself a righteous person and in return expects to be admired by the others, as if he were a businessman and dealing with honesty and ethics. Hooti and Mahmoudi (2013) implicitly aver that mankind has lost his genuine self. Actually when his shows were not charming for people anymore, the tiredness of human beings from fake ethics can be inferred. Then, the hunger artist goes to a circus in a cage close to the other animals hoping to be seen by the people and continues his show, but when the people reluctantly watch him and prefer to pay visit to the other animals, it can be stated that, this is a kind of human reference to his natural ego and spontaneity and avoiding exposing the inflexible ethics. This extract shows this matter:

it was exhilarating to watch the crowds come streaming his way, until only too soon --not even the most obstinate self-deception, clung to almost consciously, could hold out against the fact -- the conviction was borne in upon him that these people, most of them, to judge from their actions, again and again, without exception, were all on their way to the menagerie.(Kafka, 1971, p.307). 
Here, the hunger artist clearly knows the truth, and he sees the collapsing of his ideals in front of his eyes. Even though he realizes that accomplishing his ideals is almost impossible; he again somehow enjoys thinking about them, as if he could not accept that the way he had chosen, was far from the reality. In Rumi's story when the guard said to Baghdadi man:

You must be a fool to journey all this distance merely on the faith of a dream. I myself have many times dreamt of a treasure lying hid in a certain spot in Baghdad, but was never foolish enough to go there.(Rumi, 1887, p.322).

As if the Baghdadi man faced the reality, and because he was not trying to accomplish what was impossible contrary to the hunger artist, he changed his way, and his actions were based on what appeared to be the reality.

Krishnamurti implies: "unfortunately, while we are so occupied with outward activity-like the ants that are everlastingly busy-we do not see that, inwardly, we are slowly dying”.(1993, p.21). In his last words' the hunger artist properly reveals his conflict and profound dissatisfaction. The following words indicate the same:

I always wanted you to admire my fasting," said the hunger artist. "We do admire it," said the overseer, affably. "But you shouldn't admire it," said the hunger artist. "Well then we don't admire it," said the overseer, "but why shouldn't we admire it?" "Because I have to fast, I can't help it," said the hunger artist. "What a fellow you are," said the overseer, "and why can't you help it?" "Because," said the hunger artist, lifting his head a little and speaking, with his lips pursed, as if for a kiss, right into the overseer's ear, so that no syllable might be lost, "because I couldn't find the food I liked. If I had found it, believe me, I should have made no fuss and stuffed myself like you or anyone else.(Kafka, 1971, p.309).

Here, he does not know what he exactly desires; on the other hand, he only searches the sense of satisfaction in bearing and showing hunger. He does not bring his ideals under suspicion and does not think about their degree of correctness. In fact, the events that occur to him do not change his approach. So, in A Hunger Artist, maybe, the people desired to be admired by the others, but for being admired, they did not limit their lives in a limited aspect of life. In the anecdote, the guard told the Baghdadi man that he had seen several times a treasure in his dreams. Here, the place of treasure that the guard used to see in his dreams was exactly in Baghdadi man's house. So, it can symbolically refer to the ideal that the Baghdadi man used to follow is something that the other people also have in their minds, but just a few people like the Baghdadi man go to examine them. They finally reach this point that they cannot find happiness anywhere except in their own houses and actually inside themselves. The short story, A Hunger Artist shows somebody, who is staying in a cage as if he were awaiting his death, and because he cannot find his desirable food, he eats nothing. This sentence can be the symbol of an exalted will or ideal that dramatizes a man who has focused on a prominent ideal and being busy with that ideal, has forced himself to ignore the rest of things in presence. So, it can refer that he is lost or he has lost something. From an analytic vision, the panther in the last sentences of the story can refer to that missing thing, which he could not find by bearing hunger for many years. He was in the cage by his own choice, but they had put the panther in the same cage against its will. What the panther had, was the sense of freedom and great interest for living, but that artist was imprisoned by his own thoughts and judges. In fact, the panther was harmonized with the flowing of life and was like a roaring river, which that cage was only like a flagstone in its way. So, he did not remain behind the flagstone fixed, but changed its way and continued to be flowing and being alive with its full strength. This extract shows this matter:

Into the cage they put a young panther. Even the most insensitive felt it refreshing to see this wild creature leaping around the cage that had so long been dreary. The panther was all right. The food he liked was brought him without hesitation by the attendants; he seemed not even to miss his freedom; his noble body, furnished almost to the bursting point with all that it needed, seemed to carry freedom around with it too; somewhere in his jaws it seemed to lurk; and the joy of life streamed with such ardent passion from his throat that for the onlookers it was not easy to stand the shock of it. But they braced themselves, crowded around the cage, and did not want ever to move away.(Kafka, 1971, pp.309-310) .

Desires make human move and he can have limitless desires, as well. However, there is no guaranty for human desires to be fulfilled. Giddens believes: "How can we constantly keep in forefront of our minds dangers which are enormously threatening, yet so remote from individual control? The answer is that most of us cannot."(1990, pp.131132). In A Hunger Artist, the main character can be the symbol of an individual, whose main desire has not been fulfilled. His frail, thin, motionless and glum body and feature, and as well as his dissatisfaction are the symbol of a human soul that hopelessly insists on fulfilling his desire. In fact, he has a little power to continue. Rumi's story shows a man, who hopefully follows a dream in a far distant place, and this story also can be the symbol of a human being who follows an ideal as it has been dramatized in A Man of Baghdad, Therefore, this article strives to swell the coextensive interconnectedness that seems to be embodied in the both stories. Man always feels a missing spirituality in his existence as if one part of his soul cries and invites him towards itself and promises him the eternal blessing and affluence. On the other hand, he tries to gain lots of things to reach the satisfaction, which like a shadow escapes from him. There are always signs in life to show man the right way, but actually most of the time his limited thinking prevents him from changing his way. Animals instinctively find their path of life, but man sees various ways in front of himself to choose, and there are lots of factors such as culture, family, and the way he has grown up and lots of other things, which are responsible for the nature of his selection. He ordinarily looks at life from a specific point of view 
with a peculiar thinking format, and based on that specific format, chooses his life path; a safe path that lots of people have covered, so the possibility of gaining what he has in his mind can be overly high. Otteson explored:

As people find ways that allow them to successfully negotiate interactions with others, their successes, as well as their failures, are precedents that they will follow in future similar cases. Their success will also be imitated by others who observe them and also want to succeed in similar circumstances. It is in this way that social practices are born, become habits, and sometimes coalesce into principles and rules.(2006, p.323).

Meanwhile, there are few people who are against others and take step in an unsafe path and listen to their inner voices when the existing ways do not please them. These people mostly do not know what they want, they just know what they wish is beyond the typical results that others constantly talk about them, and throughout reaching these results they may consider themselves prosperous people. To be honest, man lives with his thoughts and interpretations, so what is real for someone may have another meaning for someone else. Everybody has a meaning for happiness and when one finds out that attaining his criteria of happiness is somehow impossible, he may act in two different ways, first like the Baghdadi man, who gets paranoid to his criteria and finds his thoughts false and changes his way, or he may act like the hunger artist who, hopelessly continues his way, and relates the reason of his dissatisfaction to the low and wrong comprehension of the other people. Hooti and Mahmoudi(2013) imply that human being has been encaged in the resilient unconsciousness. Baghdadi man's travel to Egypt can symbolically dramatize that, to find happiness how one gets far from itself, and how he gets alienated from his own self. So, like the hunger artist who, could have the sense of freedom and satisfaction in the cage but groped around for it in the other's judgments and admirations; he became far from himself as much that he went to a circus but people preferred to watch passionate animals rather than him. Realistically, his work was finished with no sense of satisfaction.

\section{Conclusion}

This study tried to show that man feels safe by having ideals that somehow give him pleasure, and at the same time make him feel dissatisfied. So considering excessive ideals may lead man to be negligent towards the other parts of life. An ideal by itself is not valuable for man, but hoping to get a veritable sense of satisfaction that can be resulted from them, makes man follow them. Indeed, the study strove to reveal this probable sense that was in the themes of the both stories.

Life is not predictable and is full of events that man is not prepared to confront with, so he imprisons himself in a cage which its bars are built from his thoughts and prejudgments and actually looks at the outside world through this cage, because it is much safer. Hence, most of the human beings have their own cage and through that cage interpret life. So behind every interpretation of life and its events there is a limited view and some fear of confronting what is called life.

\section{References}

Giddens, A. (1990). The Consequences of Modernity. Oxford: Polity Press \& Blackwell.

Heidegger, M. (1968). What Is Called Thinking?, Glenn Gray (Trans.). New York: Harper \& Row.

Hooti, N.\& Mahmoudi, Y. (2013). Black Veil of Ignorantism under the Unconscious Conscience of Human Soul in Shirley Jackson's Lottery. International Research Journal of Applied and Basic Sciences, 5(10), 1245-1251.

Hooti, N., \& Mahmoudi, Y. (2013). Identity Discordianism Under the Trepidation and Duplicity of Human Essence: A trenchant investigation on Luigi Pirandello'War. Theory and Practice in Language Studies, 3(7), 1209-1213.

Kafka, F. (1971). A Hunger Artist, Willa and Muir (Trans.) and N.Glatzer (Edt.). New York: Schocken Books.

Krishnamurti, J.(1993). A Timeless Spring. New York: Krishnamurti Foundation of America \& Krishnamurti Foundation Trust Ltd.

Krishnamurti, J.(1984). The Flame of Attention. New York: Harper \& Row.

Otteson, R.J.(2006). Actual Ethics. New York: Cambridge University Press.

Rumi, J.M. (1887). Masnavi i Ma'navi: The Spiritual Couplets, Whinfield (Trans.). London: Trübner and Company.

Tolle, E.(2005). A New Earth: Awakening to your life's purpose. Retrieved 11/9/2013 from

http://res.allpdftools.com/allpdftools/pdf-download-respurces/A New Earth.pdf 